Article

\title{
Conversion of Cellulose to Lactic Acid by Using $\mathrm{ZrO}_{2}-\mathrm{Al}_{2} \mathrm{O}_{3}$ Catalysts
}

\author{
Panya Wattanapaphawong ${ }^{1,2}$, Osamu Sato ${ }^{1}$, Koichi Sato ${ }^{1}$, Naoki Mimura ${ }^{1}$, \\ Prasert Reubroycharoen ${ }^{2,3}$ and Aritomo Yamaguchi ${ }^{1, *}$ \\ 1 Research Institute for Chemical Process Technology, National Institute of Advanced Industrial Science and \\ Technology (AIST), 4-2-1 Nigatake, Miyagino, Sendai 983-8551, Japan; yoyo_yok7@hotmail.com (P.W.); \\ o.satou@aist.go.jp (O.S.); koichi.sato@aist.go.jp (K.S.); n.mimura@aist.go.jp (N.M.) \\ 2 Department of Chemical Technology, Faculty of Science, Chulalongkorn University, Pathumwan, \\ Bangkok 10330, Thailand; prasert.r@chula.ac.th \\ 3 Center of Excellence on Petrochemical and Materials Technology, \\ Chulalongkorn University Research Building, Bangkok 10330, Thailand \\ * Correspondence: a.yamaguchi@aist.go.jp; Fax: +81-22-237-5226
}

Received: 26 June 2017; Accepted: 19 July 2017; Published: 21 July 2017

\begin{abstract}
Lactic acid has a wide range of applications in many industries, both as an ingredient and as an intermediate. Here, we investigated the catalytic conversion of cellulose to lactic acid by using heterogeneous mixed-oxide catalysts containing $\mathrm{ZrO}_{2}$. Although pure $\mathrm{ZrO}_{2}$ has catalytic activity for the conversion of cellulose to lactic acid, the yield of lactic acid obtained is not satisfactory. In contrast, a series of $\mathrm{ZrO}_{2}-\mathrm{Al}_{2} \mathrm{O}_{3}$ catalysts containing various percentages of $\mathrm{ZrO}_{2}$ provided higher yields of lactic acid. The $\mathrm{ZrO}_{2}-\mathrm{Al}_{2} \mathrm{O}_{3}$ catalysts had more Lewis acid sites and far fewer base sites than $\mathrm{ZrO}_{2}$. This suggests that the Lewis acid sites on $\mathrm{ZrO}_{2}-\mathrm{Al}_{2} \mathrm{O}_{3}$ catalysts are more important than the base sites for the conversion of cellulose to lactic acid.
\end{abstract}

Keywords: cellulose; lactic acid; $\mathrm{ZrO}_{2}-\mathrm{Al}_{2} \mathrm{O}_{3}$; zirconium oxide; aluminum oxide; biomass

\section{Introduction}

Biomass is a renewable organic resource that contains components that are essential for the production of many important chemicals and fuels [1-3]. Inedible lignocellulosic biomass is plant biomass that is mainly composed of cellulose, hemicellulose, and lignin. Currently, cellulose is the most promising component for biomass utilization because cellulose is the major component of lignocellulosic biomass [4-7].

Lactic acid is an organic compound that is used in large quantities as the food, cosmetic, pharmaceutical, and chemical productions [8,9]. Moreover, lactic acid is an important intermediate for conversion to other products such as propylene glycol, acrylic acid, and polylactic acid $[8,10]$. Conventionally, lactic acid is produced via the fermentation of sugars from starch [11]; however, the rate of production using this method is low, and the $\mathrm{pH}$ of the solution during fermentation must be kept in the range 5-7 to provide an environment suitable for lactic acid-fermenting bacteria. Thus, catalytic conversion of inedible cellulose is an attractive alternative to fermentation for the production of lactic acid.

Recently, several homogeneous catalysts (e.g., $\mathrm{PbCl}_{2}$ and $\mathrm{ErCl}_{3}$ ) have been investigated for their suitability for the conversion of cellulose to lactic acid [12,13]. These catalysts provide a high yield of lactic acid; however, their use in industries remains unrealized because of difficult separation of the products from the catalyst as well as the poor stability and recyclability of the catalysts. Therefore, heterogeneous catalysts for the conversion of cellulose to lactic acid are desired because products can be easily separated from this type of catalyst. Several heterogeneous catalysts have been reported to 
have catalytic activity for the conversion of cellulose to lactic acid, such as $\mathrm{LaCoO}_{3}, \mathrm{NbF}_{5}-\mathrm{AlF}_{3}$, and AlW, which provided yields of lactic acid of $24 \%, 27 \%$, and $28 \%$, respectively [14-16]. However, these solid catalysts have a disadvantage that the metal species leach into solution during the reaction-2.4\% of the $\mathrm{Co}$ and $1.5 \%$ of the $\mathrm{La}$ from $\mathrm{LaCoO}_{3}$ [14] and 1.5\% of the $\mathrm{W}$ from AlW [16] leached into solution. Additionally, these heterogeneous catalysts are relatively expensive, making their industrial use difficult. Previously, we reported a simple $\mathrm{ZrO}_{2}$ catalyst for the conversion of cellulose to lactic acid (yield, 21.2\%) that did not leach metal species into the reaction solution [17]. In addition, the $\mathrm{ZrO}_{2}$ catalyst was stable in hot water. However, the yield of lactic acid obtained with this catalyst was less than those reported for the heterogeneous catalysts. Thus, the aim of the present study was to examine how to increase the yield of lactic acid obtainable with $\mathrm{ZrO}_{2}$-based catalysts. Dispersion of active species on supports such as metal oxides is a common means of increasing the catalytic activity of heterogeneous catalysts. Therefore, here we compared the catalytic activity of a series of mixed-oxide catalysts containing various amounts of $\mathrm{ZrO}_{2}(5 \%, 10 \%$, or $20 \%)$ on an $\mathrm{Al}_{2} \mathrm{O}_{3}$ support with that of pure $\mathrm{ZrO}_{2}$. We found that the $10 \% \mathrm{ZrO}_{2}-\mathrm{Al}_{2} \mathrm{O}_{3}$ catalyst showed activity for the production of lactic acid from cellulose with a product yield of $25.3 \%$, which was cheaper than the reported heterogeneous catalysts.

\section{Results and Discussion}

\subsection{Effect of Ball-Milling Treatment on Cellulose Conversion}

In this paper, pulverization of cellulose by ball-milling has been applied for the increase of cellulose conversion [18-20]. The conversion of cellulose was only $25 \%$ in the case of un-milled cellulose ( $473 \mathrm{~K}$, $6 \mathrm{~h}$, without catalysts) and increased to $86 \%$ by the ball-milling treatment of cellulose. Figure 1 shows XRD patterns of un-milled and milled cellulose. The cellulose crystallinity was decreased by the ball-milling treatment as revealed by the peak broadening at $2 \theta=22.6$ degree (crystalline plane 002) in XRD patterns (Figure 1) $[19,21]$, indicating that the cellulose conversion increased with decreasing cellulose crystallinity. In the reaction pathway, cellulose was firstly hydrolyzed to soluble glucose; thus, cellulose with high crystallinity was hydrolyzed very slowly at $473 \mathrm{~K}$ from the result of the low conversion of un-milled cellulose.

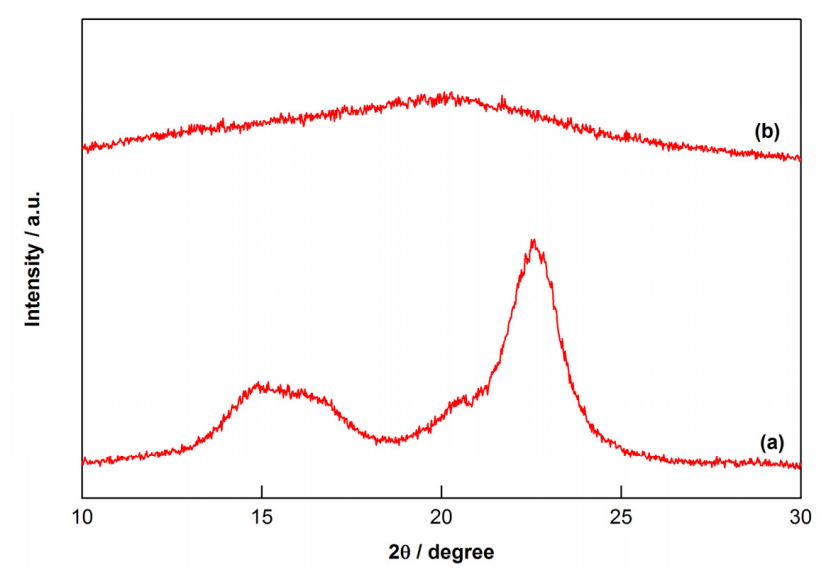

Figure 1. XRD patterns of (a) un-milled cellulose and (b) milled cellulose.

\subsection{Catalytic Conversion of Cellulose to Lactic Acid by Using $\mathrm{ZrO}_{2}-\mathrm{Al}_{2} \mathrm{O}_{3}$}

Previously, we investigated the catalytic conversion of cellulose to lactic acid by using various transition metal oxides (i.e., $\mathrm{ZrO}_{2}, \mathrm{Al}_{2} \mathrm{O}_{3}, \mathrm{TiO}_{2}, \mathrm{Fe}_{3} \mathrm{O}_{4}, \mathrm{~V}_{2} \mathrm{O}_{5}, \mathrm{CeO}_{2}, \mathrm{Y}_{2} \mathrm{O}_{3}, \mathrm{Tm}_{2} \mathrm{O}_{3}, \mathrm{HfO}_{2}, \mathrm{Ga}_{2} \mathrm{O}_{3}$, $\mathrm{MgO}, \mathrm{La}_{2} \mathrm{O}_{3}, \mathrm{Nb}_{2} \mathrm{O}_{5}$, and $\mathrm{Ta}_{2} \mathrm{O}_{5}$ ) [17]. Of these catalysts, $\mathrm{ZrO}_{2}$ had the highest catalytic activity (lactic acid yield, $21.2 \%$; reaction temperature, $473 \mathrm{~K}$ ). Therefore, in the present study, we examined the use of an $\mathrm{Al}_{2} \mathrm{O}_{3}$ support to increase the catalytic activity of $\mathrm{ZrO}_{2}$ for the conversion of cellulose to lactic acid. The yields of lactic acid obtained with $\mathrm{ZrO}_{2}-\mathrm{Al}_{2} \mathrm{O}_{3}$ mixed-oxide catalysts containing 
different percentages of $\mathrm{ZrO}_{2}$ at $473 \mathrm{~K}$ were higher than those obtained by using the individual metal oxides, indicating that the dispersion of active $\mathrm{ZrO}_{2}$ species on the $\mathrm{Al}_{2} \mathrm{O}_{3}$ support increased the catalytic activity of $\mathrm{ZrO}_{2}$ (Figure 2). The maximum yield of lactic acid (25.3\%) was obtained when $10 \% \mathrm{ZrO}_{2}-\mathrm{Al}_{2} \mathrm{O}_{3}$ was used as the catalyst. The yield of lactic acid increased slightly as the amount of $\mathrm{ZrO}_{2}$ on the $\mathrm{Al}_{2} \mathrm{O}_{3}$ support was increased from $5 \%$ to $10 \%$; however, the yield decreased as the amount of $\mathrm{ZrO}_{2}$ was increased to $20 \%$, indicating that the yield of lactic acid may decrease further as the percentage of $\mathrm{ZrO}_{2}$ on the support increases.

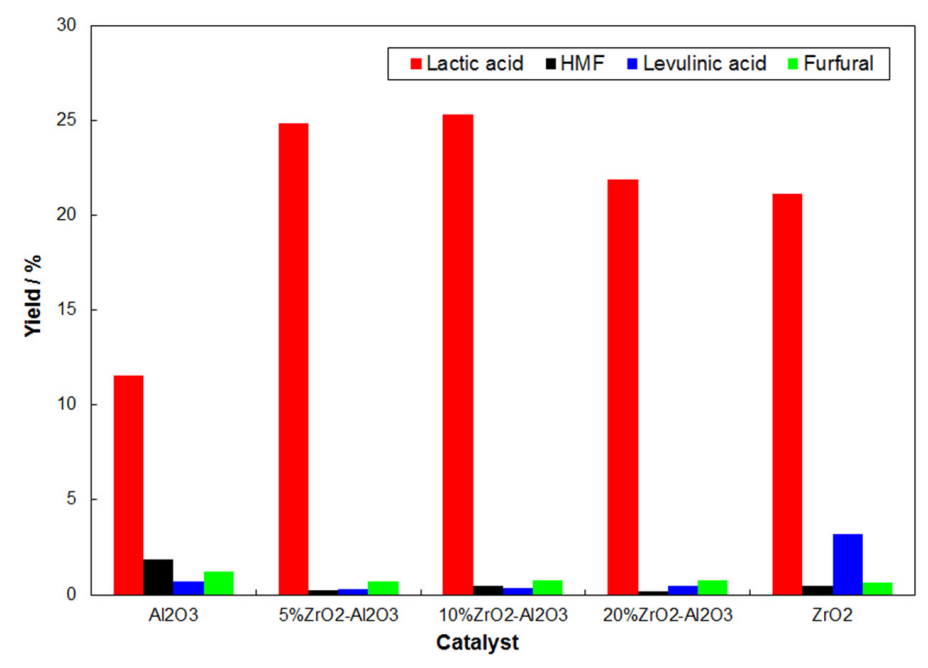

Figure 2. Product yields obtained by using $\mathrm{Al}_{2} \mathrm{O}_{3}, \mathrm{ZrO}_{2}$, or $\mathrm{ZrO}_{2}-\mathrm{Al}_{2} \mathrm{O}_{3}$ mixed-oxide catalysts for the conversion of cellulose to lactic acid. Reaction conditions: ball-milled cellulose, $0.5 \mathrm{~g}$; catalyst, $1.0 \mathrm{~g}$; water, $50 \mathrm{~g}$; reaction temperature, $473 \mathrm{~K}$; reaction time, $6 \mathrm{~h}$. HMF, 5-hydroxymethylfurfural.

\subsection{Reaction Conditions}

Next, we optimized the reaction conditions to obtain the highest possible yields of lactic acid with $10 \% \mathrm{ZrO}_{2}-\mathrm{Al}_{2} \mathrm{O}_{3}$ used as the catalyst. Figure 3 shows the product yields obtained as a function of reaction time. The yield of lactic acid increased for up to $6 \mathrm{~h}$, after which it decreased due to decomposition or polymerization of lactic acid.

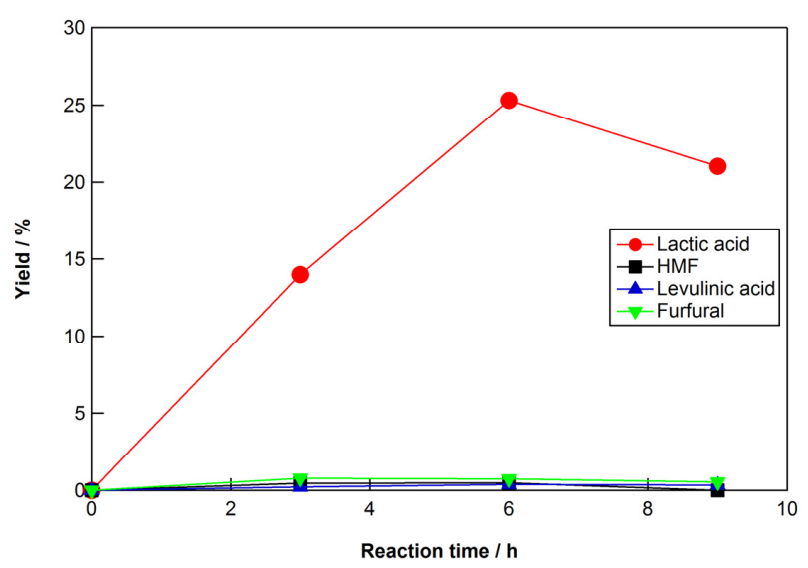

Figure 3. Product yields obtained when $10 \% \mathrm{ZrO}_{2}-\mathrm{Al}_{2} \mathrm{O}_{3}$ was used as the catalyst as a function of reaction time. Reaction conditions: ball-milled cellulose, $0.5 \mathrm{~g}$; catalyst, $1.0 \mathrm{~g}$; water, $50 \mathrm{~g}$; reaction temperature, $473 \mathrm{~K}$. HMF, 5-hydroxymethylfurfural. 
Figure 4 shows the product yields obtained as a function of reaction temperature. The maximum yield of lactic acid $(25.3 \%)$ was obtained at $473 \mathrm{~K}$. At the lowest temperature examined (i.e., $453 \mathrm{~K})$, the cellulose conversion reaction proceeded very slowly. At the highest temperature examined (i.e., $493 \mathrm{~K}$ ), the yield of lactic acid was less than that at the optimum temperature because the lactic acid was likely decomposed at this temperature.

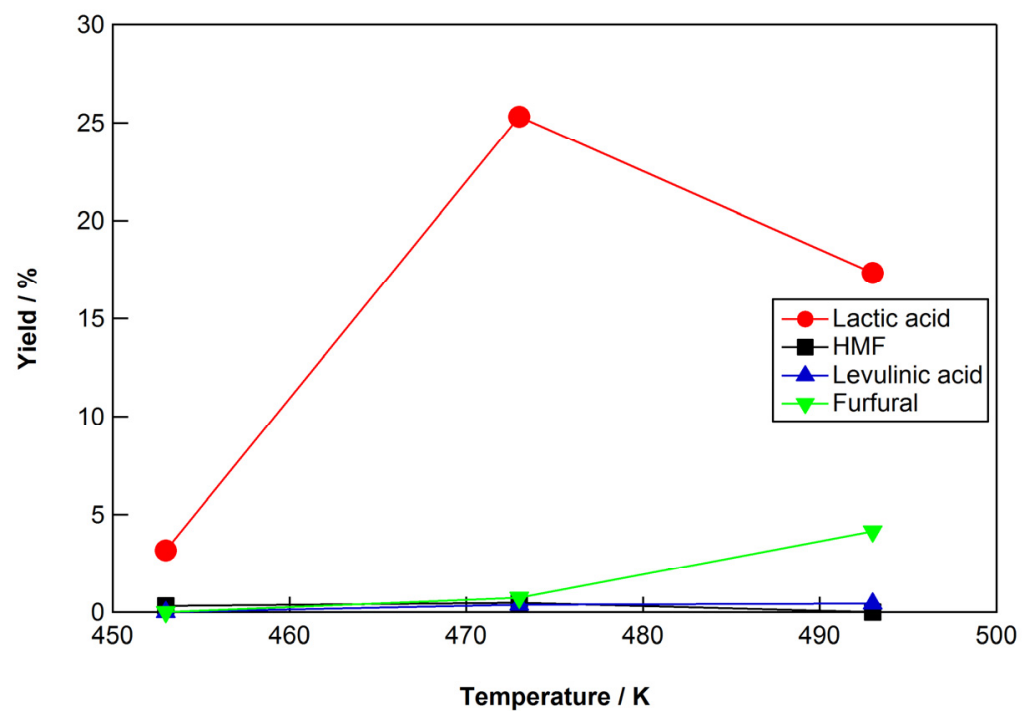

Figure 4. Product yields obtained when $10 \% \mathrm{ZrO}_{2}-\mathrm{Al}_{2} \mathrm{O}_{3}$ was used as the catalyst as a function of reaction temperature. Reaction conditions: ball-milled cellulose, $0.5 \mathrm{~g}$; catalyst, $1.0 \mathrm{~g}$; water, $50 \mathrm{~g}$; reaction time, 6 h. HMF, 5-hydroxymethylfurfural.

Finally, we investigated the reusability of the $10 \% \mathrm{ZrO}_{2}-\mathrm{Al}_{2} \mathrm{O}_{3}$ catalyst for repeated conversion of cellulose to lactic acid. After the reaction with the optimized conditions $(473 \mathrm{~K}, 6 \mathrm{~h})$, the recovered solid, which contained the used $10 \% \mathrm{ZrO}_{2}-\mathrm{Al}_{2} \mathrm{O}_{3}$ catalyst and any unreacted cellulose, was heated at $673 \mathrm{~K}$ for $15 \mathrm{~h}$ under an air atmosphere to remove carbon-based material accumulated on the surface of the catalyst. The yield of lactic acid obtained by using the reused $10 \% \mathrm{ZrO}_{2}-\mathrm{Al}_{2} \mathrm{O}_{3}$ catalyst at $473 \mathrm{~K}$ for $6 \mathrm{~h}$ was $31.7 \%$, which was higher than the yield obtained from the first reaction. One possible reason is that the calcination of the $10 \% \mathrm{ZrO}_{2}-\mathrm{Al}_{2} \mathrm{O}_{3}$ catalyst after the reaction would eliminate contamination on the surface, resulting in the higher lactic acid yield. This result suggests that the $10 \% \mathrm{ZrO}_{2}-\mathrm{Al}_{2} \mathrm{O}_{3}$ catalyst is recyclable.

\subsection{Characterization}

Next, we characterized the $\mathrm{ZrO}_{2}-\mathrm{Al}_{2} \mathrm{O}_{3}$ catalysts to further understand their catalytic activity. The X-ray diffraction (XRD) patterns of the catalysts are shown in Figure 5. In the XRD patterns of the three $\mathrm{ZrO}_{2}-\mathrm{Al}_{2} \mathrm{O}_{3}$ catalysts, peaks at $46.0^{\circ}$ and $66.5^{\circ}$ were attributed to $\gamma-\mathrm{Al}_{2} \mathrm{O}_{3}$ [22]. In the XRD patterns of $10 \% \mathrm{ZrO}_{2}-\mathrm{Al}_{2} \mathrm{O}_{3}$ and $20 \% \mathrm{ZrO}_{2}-\mathrm{Al}_{2} \mathrm{O}_{3}$, peaks at $30.3^{\circ}$ and $50.7^{\circ}$ were attributed to tetragonal $\mathrm{ZrO}_{2}$ [23]; however, these peaks were not seen in the XRD pattern of $5 \% \mathrm{ZrO}_{2}-\mathrm{Al}_{2} \mathrm{O}_{3}$, indicating that $\mathrm{ZrO}_{2}$ was either highly dispersed or in the amorphous phase in this catalyst. The XRD pattern for pure $\mathrm{ZrO}_{2}$ revealed that it was in the monoclinic phase (Figure $5 \mathrm{~d}$ ).

In our previous paper, we hypothesized that the properties of the acid and base sites on $\mathrm{ZrO}_{2}$ play an important role in the catalytic activity of this oxide for the conversion of cellulose to lactic acid [17]. Therefore, we examined the acid and base properties of the $\mathrm{ZrO}_{2}-\mathrm{Al}_{2} \mathrm{O}_{3}$ catalysts by means of temperature-programmed desorption of ammonia ( $\mathrm{NH}_{3}-\mathrm{TPD}$ ) and temperature-programmed desorption of carbon dioxide $\left(\mathrm{CO}_{2}\right.$-TPD), respectively. Figure 6 shows $\mathrm{NH}_{3}$-TPD profiles of the $\mathrm{ZrO}_{2}-\mathrm{Al}_{2} \mathrm{O}_{3}$ and $\mathrm{ZrO}_{2}$ catalysts. The $\mathrm{NH}_{3}$ desorption temperatures of the three $\mathrm{ZrO}_{2}-\mathrm{Al}_{2} \mathrm{O}_{3}$ catalysts 
were all $470 \mathrm{~K}$, which was similar to that of $\mathrm{ZrO}_{2}$, indicating that the acid sites on the $\mathrm{ZrO}_{2}-\mathrm{Al}_{2} \mathrm{O}_{3}$ and $\mathrm{ZrO}_{2}$ catalysts were weakly acidic Lewis acid sites [24] (Figure 6). The shoulder peaks at $550 \mathrm{~K}$ were observed in the case of $\mathrm{ZrO}_{2}-\mathrm{Al}_{2} \mathrm{O}_{3}$ catalysts, which were ascribed to slightly stronger acid sites than weakly acid sites (peak at $470 \mathrm{~K}$ ). The slightly stronger acid sites might be located on the boundary between $\mathrm{ZrO}_{2}$ and $\mathrm{Al}_{2} \mathrm{O}_{3}$. Although the XRD analysis revealed that the crystal phase of $\mathrm{ZrO}_{2}$ differed depending on whether it was in pure or mixed-oxide form, the $\mathrm{NH}_{3}$ desorption temperatures revealed that the acid strength was almost the same irrespective of form.

The desorption temperatures of $\mathrm{CO}_{2}$ from the $\mathrm{ZrO}_{2}-\mathrm{Al}_{2} \mathrm{O}_{3}$ and $\mathrm{ZrO}_{2}$ catalysts were in the range 340-450 K (Figure 7), indicating that the base sites on the $\mathrm{ZrO}_{2}$ catalysts were weakly basic [25]. The amount of $\mathrm{CO}_{2}$ desorbed from the $\mathrm{ZrO}_{2}-\mathrm{Al}_{2} \mathrm{O}_{3}$ catalysts was smaller than that desorbed from the $\mathrm{ZrO}_{2}$ catalyst.

Table 1 shows the amounts of acid and base sites on the $\mathrm{ZrO}_{2}-\mathrm{Al}_{2} \mathrm{O}_{3}$ and $\mathrm{ZrO}_{2}$ catalysts. The $\mathrm{ZrO}_{2}-\mathrm{Al}_{2} \mathrm{O}_{3}$ catalysts had more acid sites but far fewer base sites than the $\mathrm{ZrO}_{2}$ catalyst. In our previous paper, we suggested that the retro-aldol reaction (the conversion of fructose to glyceraldehyde and dihydroxyacetone) - the key step in the conversion of cellulose to lactic acid-involved both the acid and base sites on the $\mathrm{ZrO}_{2}$ catalyst [17]. However, the $\mathrm{ZrO}_{2}-\mathrm{Al}_{2} \mathrm{O}_{3}$ catalysts had more acid sites and far fewer base sites than did $\mathrm{ZrO}_{2}$. We discuss the reaction pathway in the next section.

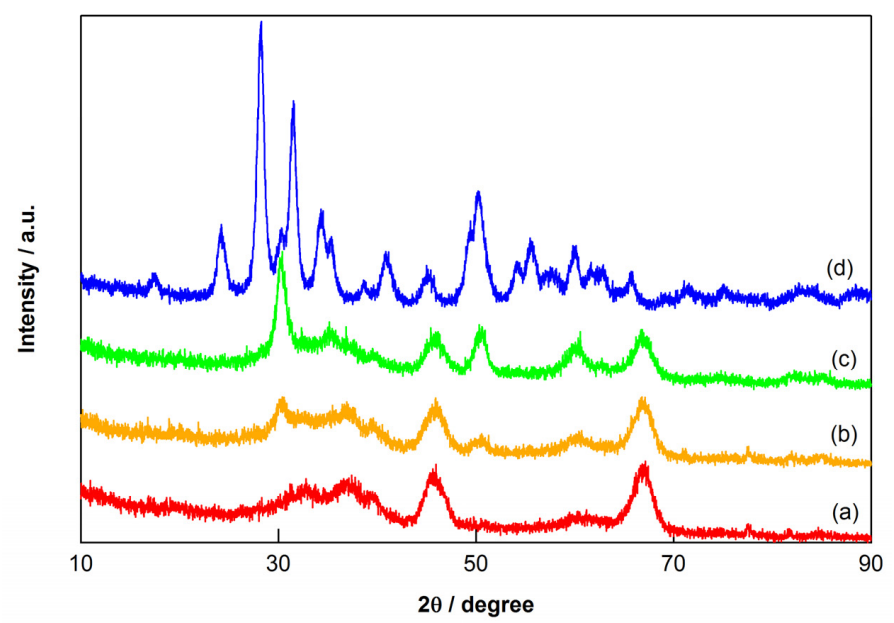

Figure 5. X-ray diffraction patterns of (a) $5 \% \mathrm{ZrO}_{2}-\mathrm{Al}_{2} \mathrm{O}_{3}$, (b) $10 \% \mathrm{ZrO}_{2}-\mathrm{Al}_{2} \mathrm{O}_{3}$, (c) $20 \% \mathrm{ZrO}_{2}-\mathrm{Al}_{2} \mathrm{O}_{3}$, and (d) $\mathrm{ZrO}_{2}$.

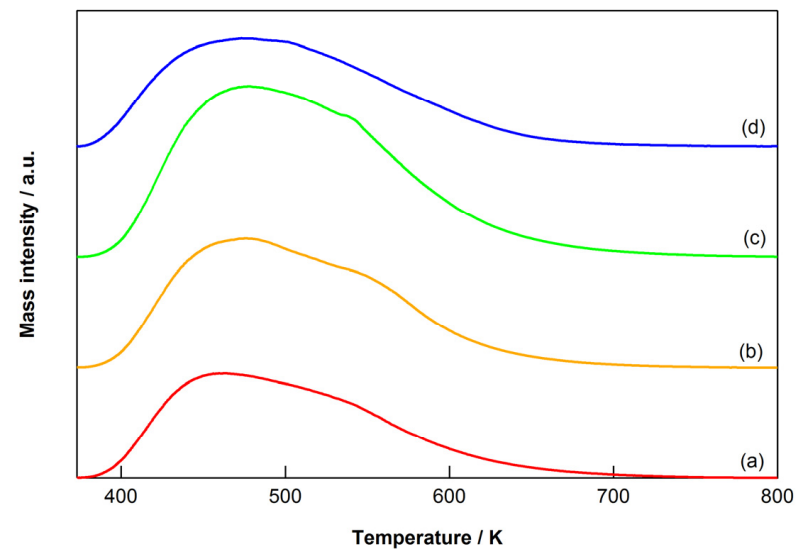

Figure 6. Temperature-programmed desorption of ammonia profiles of (a) $5 \% \mathrm{ZrO}_{2}-\mathrm{Al}_{2} \mathrm{O}_{3}$, (b) $10 \% \mathrm{ZrO}_{2}-\mathrm{Al}_{2} \mathrm{O}_{3}$, (c) $20 \% \mathrm{ZrO}_{2}-\mathrm{Al}_{2} \mathrm{O}_{3}$, and (d) $\mathrm{ZrO}_{2}$. 


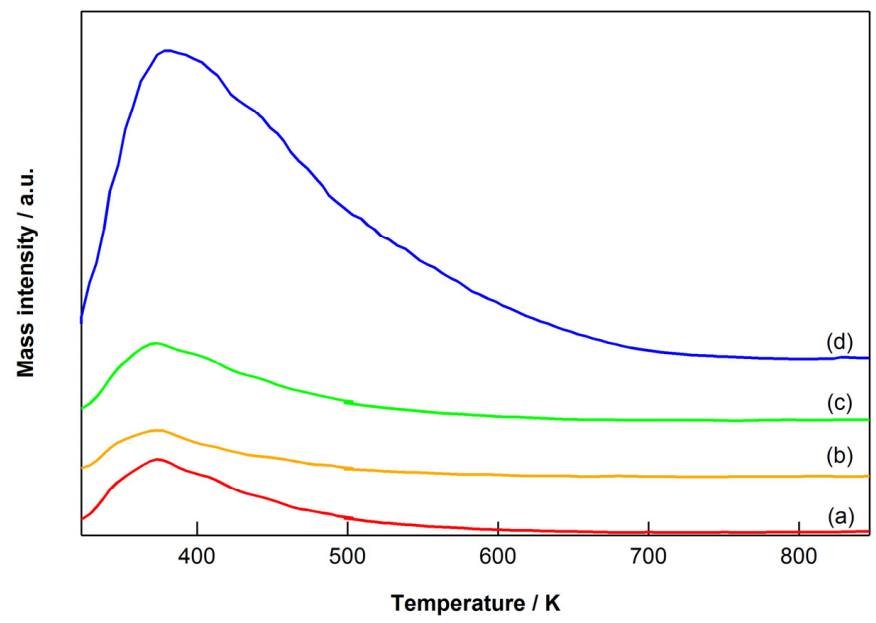

Figure 7. Temperature-programmed desorption of carbon dioxide profiles of (a) $5 \% \mathrm{ZrO}_{2}-\mathrm{Al}_{2} \mathrm{O}_{3}$, (b) $10 \% \mathrm{ZrO}_{2}-\mathrm{Al}_{2} \mathrm{O}_{3}$, (c) $20 \% \mathrm{ZrO}_{2}-\mathrm{Al}_{2} \mathrm{O}_{3}$, and (d) $\mathrm{ZrO}_{2}$.

Table 1. Properties of the $\mathrm{ZrO}_{2}-\mathrm{Al}_{2} \mathrm{O}_{3}$ and $\mathrm{ZrO}_{2}$ catalysts.

\begin{tabular}{|c|c|c|c|c|c|}
\hline Catalyst & 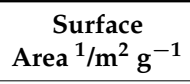 & $\begin{array}{c}\text { Crystal Phase } \\
\text { of } \mathrm{ZrO}_{2}{ }^{2}\end{array}$ & $\begin{array}{l}\text { Amount of Acid } \\
\text { Sites }^{3} / \mathrm{mmol} \mathrm{g}^{-1}\end{array}$ & $\begin{array}{l}\text { Amount of Base } \\
\text { Sites }{ }^{4} / \mathrm{mmol} \mathrm{g}^{-1}\end{array}$ & $\begin{array}{l}\text { Yield of Lactic } \\
\text { Acid } 5 \% \%\end{array}$ \\
\hline $5 \% \mathrm{ZrO}_{2}-\mathrm{Al}_{2} \mathrm{O}_{3}$ & 135 & - & 0.109 & 0.093 & 25.0 \\
\hline $10 \% \mathrm{ZrO}_{2}-\mathrm{Al}_{2} \mathrm{O}_{3}$ & 126 & Tetragonal & 0.131 & 0.057 & 25.3 \\
\hline $20 \% \mathrm{ZrO}_{2}-\mathrm{Al}_{2} \mathrm{O}_{3}$ & 130 & Tetragonal & 0.180 & 0.098 & 21.9 \\
\hline $\mathrm{ZrO}_{2} 6$ & 101 & Monoclinic & 0.118 & 0.485 & 21.2 \\
\hline
\end{tabular}

${ }^{1}$ Reported by manufacturer; ${ }^{2}$ Determined by XRD; ${ }^{3}$ Determined by temperature-programmed desorption of ammonia $\left(\mathrm{NH}_{3}-\mathrm{TPD}\right) ;{ }^{4}$ Determined by temperature-programmed desorption of carbon dioxide $\left(\mathrm{CO}_{2}-\mathrm{TPD}\right)$; ${ }^{5}$ Reaction conditions: ball-milled cellulose, $0.5 \mathrm{~g}$; catalyst, $1.0 \mathrm{~g}$; water, $50 \mathrm{~g}$; reaction temperature, $473 \mathrm{~K}$; reaction time, $6 \mathrm{~h} ;{ }^{6}$ Presented in reference [17].

\subsection{Reaction Pathway}

The conversion of cellulose to lactic acid is a multi-step reaction (Scheme 1). First, cellulose is converted to glucose by hydrolysis, which can be catalyzed by acid catalysts [26,27]. Then, glucose is isomerized to fructose by a Lewis acid or basic catalysts [28]. The key step in the conversion pathway from cellulose to lactic acid is the conversion of fructose to glyceraldehyde and dihydroxyacetone via a retro-aldol reaction involving $C-C$ bond cleavage, which can be enhanced by Lewis acids $[29,30]$. In a previous paper, we hypothesized that the combination of acid and base sites on $\mathrm{ZrO}_{2}$ enhanced the conversion of fructose to glyceraldehyde and dihydroxyacetone [17]. However, in the present study, the yield of lactic acid obtained from cellulose by using the $\mathrm{ZrO}_{2}-\mathrm{Al}_{2} \mathrm{O}_{3}$ catalysts did not appear to depend on the relative amount of acid and base sites. That is, the $\mathrm{ZrO}_{2}-\mathrm{Al}_{2} \mathrm{O}_{3}$ catalysts provided a higher yield of lactic acid than did the $\mathrm{ZrO}_{2}$ catalyst, even though they had more acid sites and far fewer base sites than did $\mathrm{ZrO}_{2}$ (Table 1). This indicates that the number of base sites is not important for the catalytic conversion of cellulose to lactic acid with $\mathrm{ZrO}_{2}-\mathrm{Al}_{2} \mathrm{O}_{3}$ catalysts. Furthermore, although the Lewis acid sites on the $\mathrm{ZrO}_{2}-\mathrm{Al}_{2} \mathrm{O}_{3}$ catalysts played an important role in the conversion of cellulose to lactic acid, the yield of lactic acid obtained was not proportional to the number of acid sites. This suggests that dispersion of $\mathrm{ZrO}_{2}$ on a $\mathrm{Al}_{2} \mathrm{O}_{3}$ support and accessibility to the acid sites on the catalyst are the most important factors for the conversion of cellulose to lactic acid when using $\mathrm{ZrO}_{2}-\mathrm{Al}_{2} \mathrm{O}_{3}$ catalysts. Further studies are required to elucidate the details of the relationship between the active sites and the product yield and also the reaction mechanism. 

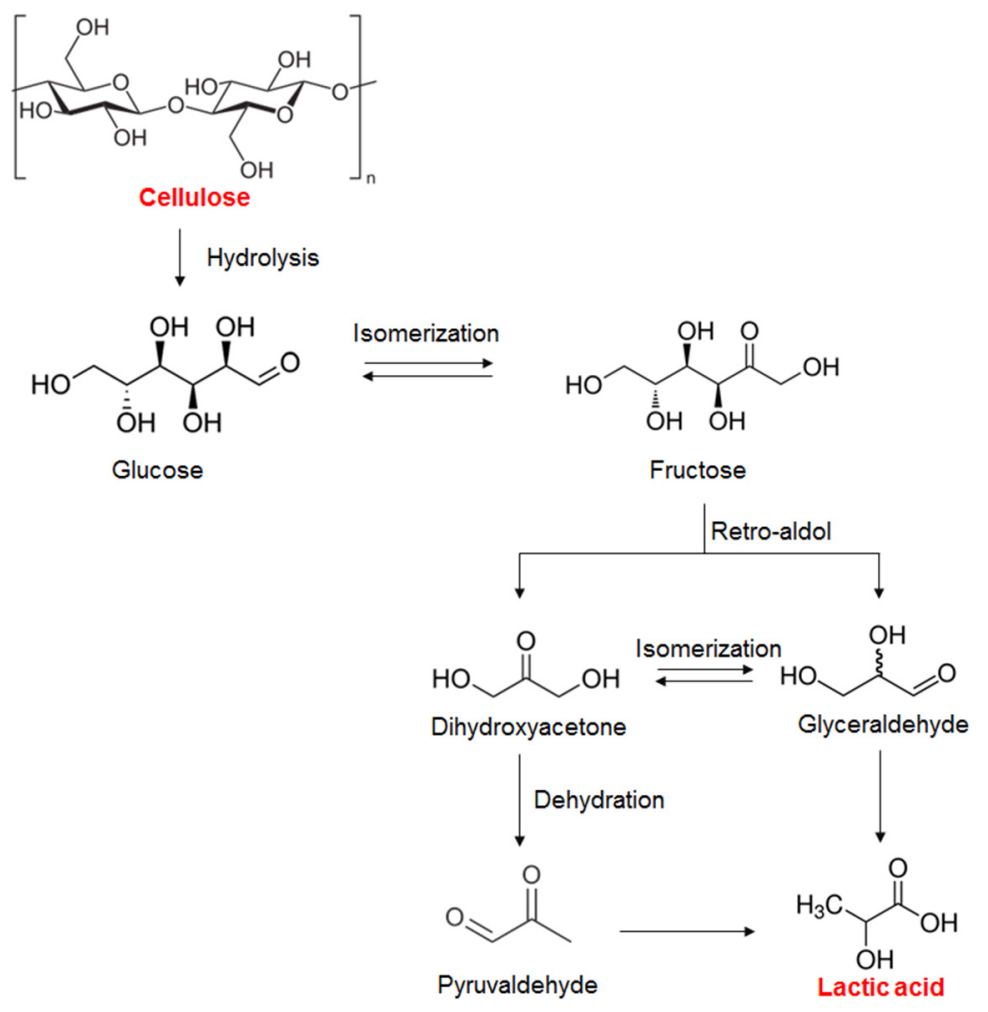

Scheme 1. Reaction pathway for the conversion of cellulose to lactic acid.

In the final step of the reaction pathway, glyceraldehyde and dihydroxyacetone can be converted to lactic acid at $463 \mathrm{~K}$ without a catalyst [17]. However, the conversion of pyruvaldehyde to lactic acid is reported to require a catalyst with Lewis acid sites [31,32], which a $\mathrm{ZrO}_{2}$-based catalyst could provide.

Previously, we reported that we used a $\mathrm{ZrO}_{2}$ catalyst to convert cellulose to lactic acid with a yield of $21.2 \%$ [17]. However, this yield of lactic acid was less than that obtained with other reported heterogeneous catalysts (24\% yield of lactic acid using $\mathrm{LaCoO}_{3}$ [14], 28\% using AlW [16], and 27\% using $\mathrm{NbF}_{5}-\mathrm{AlF}_{3}$ [15]). In the present study, we found that by using the $10 \% \mathrm{ZrO}_{2}-\mathrm{Al}_{2} \mathrm{O}_{3}$ catalyst we could obtain a yield of lactic acid of $25.3 \%$, which was comparable with the yields using the reported catalysts. One advantage of the $10 \% \mathrm{ZrO}_{2}-\mathrm{Al}_{2} \mathrm{O}_{3}$ catalyst is that it can be obtained in lower cost than the reported heterogeneous catalysts. Additionally, a few percentages of the metal species in the reported catalysts leached into solution during the reaction. Conversely, the $\mathrm{Zr}$ species was not leached out from $\mathrm{ZrO}_{2}$ into water during the reaction [17].

\section{Materials and Methods}

\subsection{Materials}

$\mathrm{ZrO}_{2}$ (ZRO-7; reference catalyst from Catalysis Society of Japan) and mixed oxides containing $\mathrm{ZrO}_{2}$ and $\mathrm{Al}_{2} \mathrm{O}_{3}\left(5 \% \mathrm{ZrO}_{2}-\mathrm{Al}_{2} \mathrm{O}_{3}, 10 \% \mathrm{ZrO}_{2}-\mathrm{Al}_{2} \mathrm{O}_{3}\right.$, and $\left.20 \% \mathrm{ZrO}_{2}-\mathrm{Al}_{2} \mathrm{O}_{3}\right)$ were obtained from Daiichi Kigenso Kagaku Kogyo Co., Ltd. (Osaka, Japan). Aluminum oxide $\left(\mathrm{Al}_{2} \mathrm{O}_{3}\right)$ was obtained from Sigma-Aldrich Co., LLC (St. Louis, MO, USA). These materials were used without pretreatment.

\subsection{Catalytic Reaction}

Cellulose (microcrystalline cellulose; Merck KGaA, Darmstadt, Germany) was pulverized with a ball mill at $60 \mathrm{rpm}$. The conversion of cellulose to lactic acid was carried out in a stainless steel batch reactor with an inner volume of $100 \mathrm{~cm}^{3}$ (MMJ-100; OM Lab-Tech, Tochigi, Japan), as described in a previous paper [17]. Briefly, the reactor was loaded with ball-milled 
cellulose $(0.5 \mathrm{~g})$, catalyst $(1.0 \mathrm{~g})$, and water $(50 \mathrm{~g})$; purged with nitrogen gas $(0.1 \mathrm{MPa})$; and then heated to $453-493 \mathrm{~K}$ for $3-9 \mathrm{~h}$ with screw stirring. After the reaction was allowed to run, the resulting mixture was filtered to separate the liquid from the solid. The quantitative analyses of lactic acid, levulinic acid, 5-hydroxymethylfurfural, and furfural in the liquid fractions were carried out with a gas chromatograph (GC-2014; Shimadzu, Kyoto, Japan) equipped with a flame ionization detector and an InertCap capillary column (GL Sciences Inc., Tokyo, Japan). The chemicals in the liquid fraction (e.g., glucose) were analyzed by using a high-performance liquid chromatograph (Shimadzu, Kyoto, Japan) equipped with a refractive index detector (RID-10A; Shimadzu, Kyoto, Japan), an ultraviolet/ visible detector (SPD-20AV; Shimadzu, Kyoto, Japan), and a Rezex RPM-Monosaccharide Pb+2 column (Phenomenex Inc., Torrance, $\mathrm{CA}, \mathrm{USA}$ ). The product yields were calculated based on moles of carbon as follows:

$$
\begin{gathered}
\text { Product yield }(\%)=\frac{(\text { Moles of carbon atoms in each product })}{(\text { Moles of carbon atoms in cellulose used })} \times 100 \\
\text { Conversion }(\%)=\left(1-\frac{(\text { Weight of solid residue })-(\text { Weight of solid catalyst })}{(\text { weight of cellulose used })}\right) \times 100
\end{gathered}
$$

\subsection{Catalyst Characterization}

XRD patterns of the catalysts were determined by using a Rigaku SmartLab XRD system (Rigaku, Tokyo, Japan) with $\mathrm{Cu} \mathrm{K} \alpha$ radiation in the $2 \theta$ range of $5-90^{\circ}$.

$\mathrm{NH}_{3}$-TPD profiles were determined with a TPD-1-AT instrument (Bel Japan, Inc., Osaka, Japan) with an online quadrupole mass spectrometer. Samples (ca. $0.05 \mathrm{~g}$ ) were pretreated at $773 \mathrm{~K}$ in flowing helium for $1 \mathrm{~h}$, saturated in flowing $5 \%$ ammonia diluted with helium $\left(0.5 \mathrm{~cm}^{3} \mathrm{~s}^{-1}\right)$ at $373 \mathrm{~K}$ for $30 \mathrm{~min}$, and then treated at $373 \mathrm{~K}$ in flowing helium $\left(0.83 \mathrm{~cm}^{3} \mathrm{~s}^{-1}\right)$ for $1 \mathrm{~h}$. The samples were then heated at a constant rate of $10 \mathrm{~K} \mathrm{~min}^{-1}$ from 373 to $953 \mathrm{~K}$ while the amount of $\mathrm{NH}_{3}$ desorbed was detected.

$\mathrm{CO}_{2}$-TPD profiles were determined with a Micromeritics 3FLEX 3500 chemisorption analyzer (Micromeritics, Norcross, GA, USA) with an online quadrupole mass spectrometer. Samples (ca. $0.2 \mathrm{~g}$ ) were pretreated at $773 \mathrm{~K}$ in flowing helium for $1 \mathrm{~h}$, saturated in flowing $\mathrm{CO}_{2}\left(0.5 \mathrm{~cm}^{3} \mathrm{~s}^{-1}\right)$ at $323 \mathrm{~K}$ for $30 \mathrm{~min}$, and then treated at $323 \mathrm{~K}$ in flowing helium $\left(0.83 \mathrm{~cm}^{3} \mathrm{~s}^{-1}\right)$ for $1 \mathrm{~h}$. The samples were then heated at a constant rate of $10 \mathrm{~K} \mathrm{~min}^{-1}$ from 323 to $953 \mathrm{~K}$ while the amount of $\mathrm{CO}_{2}$ desorbed was detected.

\section{Conclusions}

Compared with using pure $\mathrm{ZrO}_{2}$ as the catalyst (yield, 21.2\%), a greater yield of lactic acid was obtained from cellulose by using a $10 \% \mathrm{ZrO}_{2}-\mathrm{Al}_{2} \mathrm{O}_{3}$ catalyst (yield, 25.3\%) and optimized reaction conditions (reaction temperature, $473 \mathrm{~K}$; reaction time, $6 \mathrm{~h}$ ). XRD analysis revealed that the $10 \% \mathrm{ZrO}_{2}-\mathrm{Al}_{2} \mathrm{O}_{3}$ catalyst contained tetragonal $\mathrm{ZrO}_{2}$ and $\gamma-\mathrm{Al}_{2} \mathrm{O}_{3} . \mathrm{NH}_{3}-\mathrm{TPD}$ and $\mathrm{CO}_{2}-\mathrm{TPD}$ analyses revealed that all three $\mathrm{ZrO}_{2}-\mathrm{Al}_{2} \mathrm{O}_{3}$ catalysts had more Lewis acid sites and far fewer base sites than $\operatorname{did} \mathrm{ZrO}_{2}$. This suggests that the number of Lewis acid sites on the $\mathrm{ZrO}_{2}-\mathrm{Al}_{2} \mathrm{O}_{3}$ catalysts was more important than the number of base sites for the conversion of cellulose to lactic acid.

Acknowledgments: We acknowledge Daiichi Kigenso Kagaku Kogyo Co., Ltd. (Osaka, Japan) for providing the $\mathrm{ZrO}_{2}-\mathrm{Al}_{2} \mathrm{O}_{3}$ samples. This study was partially supported by a JSPS KAKENHI grant (JP17H00803), the Thailand Research Fund (IRG5780001), and an NRCT-NSFC joint funding project (NRCT/2558-104).

Author Contributions: P.W. and A.Y. conceived and designed the experiments; P.W. performed the catalytic reaction experiments; O.S. and N.M. analyzed the data; K.S. performed the $\mathrm{NH}_{3}$-TPD study; P.W., P.R., and A.Y. wrote the paper; all the authors discussed the results and commented on the manuscript.

Conflicts of Interest: The authors declare no conflict of interest. 


\section{References}

1. Huber, G.W.; Iborra, S.; Corma, A. Synthesis of Transportation Fuels from Biomass: Chemistry, Catalysts, and Engineering. Chem. Rev. 2006, 106, 4044-4098. [CrossRef] [PubMed]

2. Petrus, L.; Noordermeer, M.A. Biomass to biofuels, a chemical perspective. Green Chem. 2006, 8, 861-867. [CrossRef]

3. Corma, A.; Iborra, S.; Velty, A. Chemical Routes for the Transformation of Biomass into Chemicals. Chem. Rev. 2007, 107, 2411-2502. [CrossRef] [PubMed]

4. Kobayashi, H.; Komanoya, T.; Guha, S.K.; Hara, K.; Fukuoka, A. Conversion of cellulose into renewable chemicals by supported metal catalysis. Appl. Catal. A 2011, 409-410, 13-20. [CrossRef]

5. Gallezot, P. Conversion of biomass to selected chemical products. Chem. Soc. Rev. 2012, 41, 1538-1558. [CrossRef] [PubMed]

6. Yamaguchi, A. Biomass Valorization in High-temperature Liquid Water. J. Jpn. Petrol. Inst. 2014, 57, $155-163$. [CrossRef]

7. Yamaguchi, A.; Sato, O.; Mimura, N.; Shirai, M. One-pot conversion of cellulose to isosorbide using supported metal catalysts and ion-exchange resin. Catal. Commun. 2015, 67, 59-63. [CrossRef]

8. Datta, R.; Henry, M. Lactic acid: recent advances in products, processes and technologies-A review. J. Chem. Technol. Biotechnol. 2006, 81, 1119-1129. [CrossRef]

9. Mäki-Arvela, P.; Simakova, I.L.; Salmi, T.; Murzin, D.Y. Production of Lactic Acid/Lactates from Biomass and Their Catalytic Transformations to Commodities. Chem. Rev. 2014, 114, 1909-1971. [CrossRef] [PubMed]

10. Garlotta, D. A Literature Review of Poly(Lactic Acid). J. Polym. Environ. 2001, 9, 63-84. [CrossRef]

11. Martinez, F.A.C.; Balciunas, E.M.; Salgado, J.M.; González, J.M.D.; Converti, A.; Oliveira, R.P.D.S. Lactic acid properties, applications and production: A review. Trends Food Sci. Technol. 2013, 30, 70-83. [CrossRef]

12. Wang, Y.; Deng, W.; Wang, B.; Zhang, Q.; Wan, X.; Tang, Z.; Wang, Y.; Zhu, C.; Cao, Z.; Wang, G.; et al. Chemical synthesis of lactic acid from cellulose catalysed by lead(II) ions in water. Nat. Commun. 2013, 4, 2141. [CrossRef] [PubMed]

13. Lei, X.; Wang, F.-F.; Liu, C.-L.; Yang, R.-Z.; Dong, W.-S. One-pot catalytic conversion of carbohydrate biomass to lactic acid using an $\mathrm{ErCl}_{3}$ catalyst. Appl. Catal. A 2014, 482, 78-83. [CrossRef]

14. Yang, X.; Yang, L.; Fan, W.; Lin, H. Effect of redox properties of $\mathrm{LaCoO}_{3}$ perovskite catalyst on production of lactic acid from cellulosic biomass. Catal. Today 2016, 269, 56-64. [CrossRef]

15. Coman, S.M.; Verziu, M.; Tirsoaga, A.; Jurca, B.; Teodorescu, C.; Kuncser, V.; Parvulescu, V.I.; Scholz, G.; Kemnitz, E. $\mathrm{NbF}_{5}-\mathrm{AlF}_{3}$ Catalysts: Design, Synthesis, and Application in Lactic Acid Synthesis from Cellulose. ACS Catal. 2015, 5, 3013-3026. [CrossRef]

16. Chambon, F.; Rataboul, F.; Pinel, C.; Cabiac, A.; Guillon, E.; Essayem, N. Cellulose hydrothermal conversion promoted by heterogeneous Brønsted and Lewis acids: Remarkable efficiency of solid Lewis acids to produce lactic acid. Appl. Catal. B 2011, 105, 171-181. [CrossRef]

17. Wattanapaphawong, P.; Reubroycharoen, P.; Yamaguchi, A. Conversion of cellulose into lactic acid using zirconium oxide catalysts. RSC Adv. 2017, 7, 18561-18568. [CrossRef]

18. Teramoto, Y.; Tanaka, N.; Lee, S.-H.; Endo, T. Pretreatment of eucalyptus wood chips for enzymatic saccharification using combined sulfuric acid-free ethanol cooking and ball milling. Biotechnol. Bioeng. 2008, 99, 75-85. [CrossRef] [PubMed]

19. Yamaguchi, A.; Hiyoshi, N.; Sato, O.; Bando, K.K.; Shirai, M. Gaseous Fuel Production from Nonrecyclable Paper Wastes Using Supported Metal Catalysts in High-Temperature Liquid Water. ChemSusChem 2010, 3, 737-741. [CrossRef] [PubMed]

20. Yamaguchi, A.; Sato, O.; Mimura, N.; Hirosaki, Y.; Kobayashi, H.; Fukuoka, A.; Shirai, M. Direct Production of Sugar Alcohols from Wood Chips using Supported Platinum Catalysts in Water. Catal. Commun. 2014, 54, 22-26. [CrossRef]

21. Zhao, H.; Kwak, J.H.; Wang, Y.; Franz, J.A.; White, J.M.; Holladay, J.E. Effects of Crystallinity on Dilute Acid Hydrolysis of Cellulose by Cellulose Ball-Milling Study. Energy Fuels 2006, 20, 807-811. [CrossRef]

22. Said, A.E.-A.A.; El-Wahab, M.M.M.A.; El-Aal, M.A. Effect of $\mathrm{ZrO}_{2}$ on the catalytic performance of nano $\gamma-\mathrm{Al}_{2} \mathrm{O}_{3}$ in dehydration of methanol to dimethyl ether at relatively low temperature. Res. Chem. Intermed. 2016, 42, 1537-1556. [CrossRef] 
23. Zhang, D.; Duan, A.; Zhao, Z.; Wan, G.; Gao, Z.; Jiang, G.; Chi, K.; Chuang, K.H. Preparation, characterization and hydrotreating performances of $\mathrm{ZrO}_{2}-\mathrm{Al}_{2} \mathrm{O}_{3}$-supported NiMo catalysts. Catal. Today 2010, 149, $62-68$. [CrossRef]

24. Manríquez, M.E.; López, T.; Gómez, R.; Navarrete, J. Preparation of $\mathrm{TiO}_{2}-\mathrm{ZrO}_{2}$ mixed oxides with controlled acid-basic properties. J. Mol. Catal. A 2004, 220, 229-237. [CrossRef]

25. Ma, Z.-Y.; Yang, C.; Wei, W.; Li, W.-H.; Sun, Y.-H. Surface properties and CO adsorption on zirconia polymorphs. J. Mol. Catal. A 2005, 227, 119-124. [CrossRef]

26. Rinaldi, R.; Schuth, F. Acid Hydrolysis of Cellulose as the Entry Point into Biorefinery Schemes. ChemSusChem 2009, 2, 1096-1107. [CrossRef] [PubMed]

27. Wang, J.; Xi, J.; Wang, Y. Recent advances in the catalytic production of glucose from lignocellulosic biomass. Green Chem. 2015, 17, 737-751. [CrossRef]

28. Delidovich, I.; Palkovits, R. Catalytic Isomerization of Biomass-Derived Aldoses: A Review. ChemSusChem 2016, 9, 547-561. [CrossRef] [PubMed]

29. Yang, L.; Yang, X.; Tian, E.; Lin, H. Direct Conversion of Cellulose into Ethyl Lactate in Supercritical Ethanol-Water Solutions. ChemSusChem 2016, 9, 36-41. [CrossRef] [PubMed]

30. Yang, L.; Yang, X.; Tian, E.; Vattipalli, V.; Fan, W.; Lin, H. Mechanistic insights into the production of methyl lactate by catalytic conversion of carbohydrates on mesoporous Zr-SBA-15. J. Catal. 2016, 333, 207-216. [CrossRef]

31. Pescarmona, P.P.; Janssen, K.P.F.; Delaet, C.; Stroobants, C.; Houthoofd, K.; Philippaerts, A.; De Jonghe, C.; Paul, J.S.; Jacobs, P.A.; Sels, B.F. Zeolite-catalysed conversion of C3 sugars to alkyl lactates. Green Chem. 2010, 12, 1083-1089. [CrossRef]

32. Nakajima, K.; Noma, R.; Kitano, M.; Hara, M. Titania as an Early Transition Metal Oxide with a High Density of Lewis Acid Sites Workable in Water. J. Phys. Chem. C 2013, 117, 16028-16033. [CrossRef]

(C) 2017 by the authors. Licensee MDPI, Basel, Switzerland. This article is an open access article distributed under the terms and conditions of the Creative Commons Attribution (CC BY) license (http:/ / creativecommons.org/licenses/by/4.0/). 